\title{
Effect of Biofertilizers on Vegetative Growth and Yield of Hibiscus sabdariffa, L. Plants under Different Concentrations of Saline Irrigation
}

\author{
A.H.M. El-Naggar ${ }^{1}$; H.M. El-Kouny ${ }^{2}$
}

\begin{abstract}
The present work was carried out during the two successive seasons 2008and 2009 in the experimental station of soil salinity and alkalinity laboratory, Alex., to study the effect of inoculation with the biofertilizers [Nitrobine+Phosphorein(NP) 1:1 w/w] at rates 0.0,2.5,5and $10 \mathrm{~g} /$ plant and salinized water ( $\mathrm{EC}, 2,4$ and $8 \mathrm{dSm}^{-1}$ ) and their combinations on the growth, yield and chemical content of leaves and sepales of Hibiscus sabdariffa, $L$. plants. In addition soil EC, pH, SAR and NPK availability were determined.

The results indicated that increasing rates of the biofertilizers Nitrobine+Phosphorein (NP) resulted in considerable significant increases in all growth parameters [plant height $(\mathrm{cm})$, number of branches / plant, number of leaves, dry weight of leaves / plant (g)] and yield [number of fruits / plant, fresh and dry weights of fruits / plant(g)]. Anthocyanine pigments and vitamin $\mathrm{C}$ and total chlorophyll content and mineral content ( N,P and $K \%)$ were increased. The highest increase in these characters were obtained from adding the biofertilizers at rate $10 \mathrm{~g} /$ plant combined with $\mathrm{EC}, 2 \mathrm{dSm}^{-1}$ saline water irrigation - Also, the increment applications of biofertilizers(NP) at any levels of irrigation water salinity imposed considerable reduction in soil $\mathrm{pH}, \mathrm{EC}$ and $\mathrm{SAR}$. In the contrary, soil available N,P and Kwere progressively increased with increasing application rates of biofertilizers(NP) at 5 and/or $10 \mathrm{~g} /$ plant across salinity treatment. The highest value were performed with $10 \mathrm{~g} /$ plant biofertilizers(NP) with saline water level of $\mathrm{EC}, 2 \mathrm{dSm}^{-1}$
\end{abstract}

Key words: Hibiscus sabdariffa, L., Roselle plant, medicinal plant, Biofertilizers, Nitrobine,Phosphorein ,Salinity, available nutrients, Anthocyanine pigment, Vitamin C.

\section{INTRODUCTION}

Roselle plant (Hibiscus sabdariffa, L. - Malvaceae family) is an annual or perennial herb or woody-based shrubs growing $2 \mathrm{~m}$. tall with branched,erected smooth and often purplish stem and known in Egypt as "Karkade". The main product of this crop is the dried fleshy epicalyxes and calyx (fruits) which is used as a source of vitamin $\mathrm{C}$, diuretic, mild laxative and intestinal antiseptic. It reduces blood pressure and stimulates intestinal peristalsis. The red coloring matter is used in cosmetics, jams, and used as a poultice on abscess. The dried red sepals are used for preparing cold and hot soft drink. Also Roselle is an important plant for its high anthocyanin contents.

Environmental stress and potential pollution of natural resources are due to the excessive use of chemical fertilizers under intensive agricultural systems to meet the demands of the overpopulated societies. This may pose health hazards. Therefore, alternative agriculture such as using microorganisms as biofertilizers in agriculture is considered to be a way to preserve the environment and prevent pollution (Ramadan et al., 2002). In addition to their expensive costs, chemical fertilizers might suppress the activity of microflora and stability of soil organic matter. Biological fertilizers provide an alternative to agricultural chemicals as more sustainable and ecologically sound practice to increase crop productivity .This approach has been the most recent scope of many researchers. Recent investigations revealed that the application of biofertilizers to the soils can promote nutrients availability and plant uptake, increase crop yield, reduce inputs of chemical fertilizers and minimize environmental risks (Barsoom, 1998; Khalid et al., 2000; Koreish, 2003 and Koreish et al., 2004).

Saline water irrigation is considered detrimental to most crop plants. Even salt-resistant plants show decrease in yield when grown under saline irrigation. However, saline water is available in abundance in many countries of the world, thus, the importance of establishing agro-management regimes that include saline water is self-evident.

In arid and semi arid regions, salinity has been recognized as an important factor influencing crop production and agricultural sustainability. On the other hand, irrigation with saline water without proper management, such as mixing with fresh water, would produce adverse effects on crop yield and soil productivity due to deterioration of soil quality (Afifi $e t$ al., 1998 and Morsy, 2003).

The objectives of this study were 1) to elucidate the combination effect of biofertilizers and irrigation water salinity on growth, yield and quality of Hibiscus

\footnotetext{
${ }^{1}$ Floriculture, Ornamental Horticulture and landscape Gardening Dept., Faculty of Agric., (EL-Shatby), Alexandria Univ. Egypt.

${ }^{2}$ Soil Salinity Res. Lab., Alex.; Soil, water and Enviro. Res.

Institute; Agric. Res. Center, Alexandria, Egypt.

Received Febuary16, 2011, Accepted March3, 2011
} 
sabdariffa,L. plant, 2) chemical composition of sepals and leaves 3) to assess their effectiveness on some chemical properties and nutritional status of the used experimental soil

\section{MATERIALS AND METHODS}

The pot experimental study was carried out at the experimental station of Soil Salinity and Alkalinity Laboratory, Alexandria, Egypt throughout the two successive growing seasons of 2008 and 2009 under open field condition.

\section{The growing medium:}

Pots (40 $\mathrm{cm}$ in diameter) were packed with clay soil collected from Kafr-ELDawar district. Each pot contained $20 \mathrm{Kg}$ medium. Analysis of some chemical and physical properties of the used medium were carried out according to Page et al. (1982) and are presented in Table(1):

Table1. The main chemical and physical properties of the growing medium

\begin{tabular}{|c|c|}
\hline Soil properties & The value \\
\hline $\mathrm{pH}$ & 8.10 \\
\hline $\mathrm{EC}\left(\mathrm{dS} \mathrm{m}^{-1}\right)$ & 2.75 \\
\hline CEC $\left(\mathrm{cmol} \mathrm{Kg}^{-1}\right)$ & 45.00 \\
\hline O.M, \% & 1.85 \\
\hline $\operatorname{Av}-\mathrm{N}\left(\mathrm{mg} \mathrm{Kg}^{-1}\right)$ & 21.50 \\
\hline $\mathrm{Av}-\mathrm{P}\left(\mathrm{mg} \mathrm{Kg}^{-1}\right)$ & 11.50 \\
\hline $\mathrm{Av}-\mathrm{K}\left(\mathrm{mg} \mathrm{Kg}^{-1}\right)$ & 77.50 \\
\hline \multicolumn{2}{|l|}{ Soluble cations: } \\
\hline $\mathrm{Ca}^{2+} \mathrm{meq} / \mathrm{L}$ & 5.30 \\
\hline $\mathrm{Mg}^{2+} \mathrm{meq} / \mathrm{L}$ & 2.80 \\
\hline $\mathrm{K}^{+} \quad \mathrm{meq} / \mathrm{L}$ & 1.60 \\
\hline $\mathrm{Na}^{+} \quad$ meq/L & 17.80 \\
\hline \multicolumn{2}{|l|}{ Soluble anions: } \\
\hline $\mathrm{CO}_{3}{ }^{2-} \mathrm{meq} / \mathrm{L}$ & 0.00 \\
\hline $\mathrm{H} \mathrm{CO}_{3}^{-} \mathrm{meq} / \mathrm{L}$ & 3.20 \\
\hline $\mathrm{Cl}^{-} \mathrm{meq} / \mathrm{L}$ & 17.20 \\
\hline $\mathrm{SO}_{4}^{2-} \mathrm{meq} / \mathrm{L}$ & 4.10 \\
\hline Soil field capacity $\%$ & 35.50 \\
\hline SAR & 8.4 \\
\hline Total calcium carbonate, $\%$ & 6.75 \\
\hline \multicolumn{2}{|l|}{ Particle size distribution } \\
\hline Sand $\%$ & 16.10 \\
\hline Silt $\%$ & 23.70 \\
\hline Clay $\%$ & 60.20 \\
\hline Soil texture class & Clay \\
\hline
\end{tabular}

\section{Experimental treatments and layout:}

The experimental treatments were consisted of four rates $(0.0,2.5,5$ and $10 \mathrm{~g} / \mathrm{plant})$ of biofertilizers [Nitrobine +Phosphorein(NP)1:1w/w] used and four concentrations of water saline irrigation i.e. (tap water as control) 0.312 $\mathrm{dSm}^{-1}, 2 \mathrm{dSm}^{-1}, 4 \mathrm{dSm}^{-1}$ and $8 \mathrm{dSm}^{-1}$. The saline irrigation water treatments were prepared by dilution of sea water with tap water to the required salt concentrations. The biofertilizers nitrobine contains two non-symbiotic nitrogen fixing bacteria, Azotobacter chroococcum and Azospirillum barasilense carried on peat moss, vermiculite and plant charcoal (Shalan, et al., 2001). Phosphorein containing phosphate dissolving vesicular and arbuscular mycorrhiza and Silicane bacteria (Abdalla et al., 2001)and four. The biofertilizers was added to the growing medium with a rate of $0.0,2.5,5$ and $10 \mathrm{~g} / \mathrm{plant}$ divided into two equal doses. The first dose was added before planting, while the second was applied one month later. All pots had received a basal dose of five grams of farm yard manure (FYM)/ pot (moisture $18 \%$ ) were added a few days before planting and mixed with soil of the experiment. The analysis of the used manure gave $0.83 \%, \mathrm{~N} 0.26 \%$ $\mathrm{P}$, and $0.19 \% \mathrm{~K}$.

The experimental layout was split-plot design for arrangement of pots with three replicates. five plants were used for each treatment in the replicate( Snedecor and cochran ,1981). The biofertilizers were arranged in the main treatments, While the water salinity concentrations were randomly distributed in the subtreatments and all were treated under open field condition. Roselle seeds, Hibiscus sabdariffa,L. c v. "Sabahia 17" were sown in each pot at about $3 \mathrm{~cm}$ depth from soil surface in two successive summer seasons (June 2008 and June 2009). The pots were lightly irrigated for two weeks before planting with tap water, to establish a good microbial activity for decomposing manure material before sowing of seeds . The seedling were thinned out to one plant in each pot after four weeks from sowing. The pots were then irrigated every two days with the tested water treatments. The moisture content in growing medium was kept at $70 \%$ of soil water-holding capacity (El-Kouny et al., 2010).

\section{Morphological Measurements:}

At the end of each growing season the following morphological measurements were carried out on the grown roselle plants:

1- Vegetative growth characteristics: Plant height $(\mathrm{cm})$, number of branches/ plant, number of leaves and dry weight of leaves / plant ( $\mathrm{g}$ ).

2- Yield parameters : Number of fruits/ plant, fresh and dry weights of fruits / plant (g).

\section{Plant and Soil Analyses:}

1- At the flower bud initiation stage of each growing season, the total chlorophylls content $(\mathrm{mg} / 100 \mathrm{~g}$ fresh weight) of the fresh leaves of the plants was determined by direct spectrophotometer method according to Moran and Porath (1980). 
2- The concentration of anthocyanine pigment and vitamin $\mathrm{C}(\mathrm{mg} / 100 \mathrm{gm})$ in the mature sepals were determined as described by Fahmy (1970).

3- In addition, chemical analyses of oven-dry leaves (dried at $60{ }^{\circ} \mathrm{C}$ for $72 \mathrm{hr}$ ) were carried to determine their $\mathrm{N}, \mathrm{P}$ and $\mathrm{K}$ contents (\%) according to the methods outlined by Westerman (1990).

4- Soil samples were taken from each treatment for determination of the different chemical analysis at the end of the experiment according to Page et al.,(1982)

The same steps and techniques of the first experimental year (2008) were followed in the second one(2009). The data were statistically analyzed according to the methods described by Snedecor and Cochran, (1981) using L.S.D. to compare between means of treatments.

\section{RESULTS AND DISCUSSIONS}

\section{Vegetative growth}

\section{1- Plant height}

The data in Table (2) showed that the biofertilizers (NP) application $(2.5,5$ and $10 \mathrm{~g} /$ plant $)$ produced significant increases in plant height of Hibiscus sabdariffa,L. c v. "Sabahia 17" plants at harvest time as compared with the control treatment of the two growing seasons. Generally, there were significant increases in plant height by increasing the rate of biofertilizers(NP) up to $10 \mathrm{~g} /$ plant. The highest values of plant height were obtained by addition of biofertilizers (NP) at a rate $10 \mathrm{~g} / \mathrm{plant}$ as comparing with the control for the two seasons. This treatment led to an increase of plant height by $74.57 \%$ and $79.20 \%$ as the average of relative increase, over the control for both seasons, respectively. These results are in agreement with those obtained by Jayathilake et al. (2002) and Rather et al. (2003) on onion and El-Naggar and Hedia (2005) on Narcissus tazetta, L. who reported that the maximum plant height were recorded with Azotobacter and Azospirillum inoculation.

It is evident from the obtained data in Table (2) clear that plant height decreased with increasing of EC level, except water saline at EC $2 \mathrm{dSm}^{-1}$ in both seasons. The differences between treatments of control (tap water) and EC, $2 \mathrm{dSm}^{-1}$ salinity treatment were non significant in the first and second seasons. While the lowest ones resulted from applied water EC, $8 \mathrm{dSm}^{-1}$ in both seasons, respectively. These results are somewhat like that obtained by El-Sayed and El-Naggar (2008) on Euphorbia pluchrrima plants.

Data presented in Table (2) clearly indicated that plant height was significantly increased with increasing biofertilizer (NP) rate $(2.5,5$ and $10 \mathrm{~g} / \mathrm{plant})$ in combined with concentration of water salinity at EC 2 $\mathrm{dSm}^{-1}$, as compared with the control treatment in the two growing seasons. The highest values of plant height were obtained by biofertilizers inoculation (NP) at rate $10 \mathrm{~g} /$ plant and water salinity at EC, $2 \mathrm{dSm}^{-1}$ as compared with the other treatments in the two season. The values reached 147.29 and $150.15 \mathrm{~cm}$ against 86.79 and 85.38 $\mathrm{cm}$ resulted from the control treatment in the first and second seasons, respectively. The differences between treatments of $10 \mathrm{~g}$ biofertilizer with tap water and /or EC, $2 \mathrm{dSm}^{-1}$ were non significant in the first and second seasons. The results related to the effect of addition of biofertilizer with lower levels of water salinity which improved the availability and absorption of the nutrient elements leading to increase the growth plant. Biofertilizers applications resulted in a promoting effect on plant growth expressed as plant height, this may be due to that total nitrogen fixation might be increased by increasing the available phosphorus in the soil which released by phosphate solubilization and mineralization process caused by the phosphate dissolving bacteria. Phosphate is known to regulate many enzymatic process, also, act as an activator of some enzymes, leading to enhancement of the metabolism processes and formation of new cells (Dhillon, 1987), consequently, increasing the vegetative growth. Also, the phosphorus plays major roles in protein synthesis and protoplasm formation leading to an increase in cell size. In addition to the role of phosphorus in increasing the root system and in the biosynthesis of energy rich phosphate compounds, such as adenosine triphosphate (ATP), which is implicated in ion absorption (Marschner, 1986). On the other hand, the reduction of plant height under high salinity without inoculation of biofertilizer application may be due to the accumulation of the salts in the soil which increased the osmatic pressure of tissue cells of plant and depressed water absorption. This is elso related to the reduction in cambium activity and maturation of smaller cell size (Wareing and Phillips, 1974). These results are in agreement with those obtained by Osbrien and Barker (1996) on Mentha piparita plants and El-Sayed and ElNaggar (2008) on Euphorbia pluchrrima plants.

\section{2- Number of branches / plant}

Evidently data in Table (2) show that all biofertilizers (NP) treatments significantly increased this parameter compared with the control. Generally, number of branches/plant were significantly increased by increasing the rate of biofertilizers(NP) up to $10 \mathrm{~g} / \mathrm{plant}$. The highest number of branches / plant detected with plants received NP with rates (10g/plant). It increased number of branches / plant to 7.19 and 6.80 in the first and second seasons, respectively. 
Table 2. Effect of biofertilizers, water salinity and their interaction on plant height $(\mathrm{cm})$ and number of branches/plant of Hibiscus sabdariffa, L. cv. "Sabhia 17" plants during the 2008 and 2009 seasons

\begin{tabular}{|c|c|c|c|c|c|c|c|c|c|c|}
\hline \multirow{2}{*}{$\begin{array}{l}\text { Bio. } \\
\text { rate, }\end{array}$} & \multicolumn{10}{|c|}{ 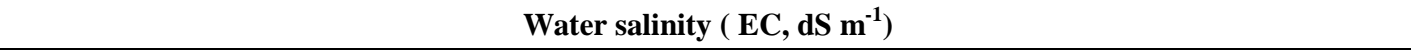 } \\
\hline & T.W & 2 & 4 & 8 & Mean & T.W & 2 & 4 & 8 & Mean \\
\hline \multirow[t]{2}{*}{ g / plant } & \multicolumn{10}{|c|}{ Plant height ( cm ) } \\
\hline & \multicolumn{5}{|c|}{$\left(1^{\text {st }}\right)$ season } & \multicolumn{5}{|c|}{$\left(2^{\text {nd }}\right)$ season } \\
\hline $\mathbf{0}$ & 86.79 & 84.82 & 79.24 & 73.39 & 81.06 & 85.38 & 82.46 & 80.23 & 75.59 & 80.91 \\
\hline 2.5 & 97.57 & 102.32 & 98.58 & 94.25 & 98.18 & 94.30 & 99.50 & 98.08 & 95.35 & 96.82 \\
\hline 5 & 132.39 & 135.13 & 119.37 & 116.28 & 125.79 & 135.96 & 137.78 & 121.21 & 114.96 & 126.48 \\
\hline 10 & 146.98 & 147.29 & 142.20 & 129.59 & 141.51 & 148.22 & 150.19 & 140.29 & 129.28 & 144.99 \\
\hline Mean & 115.93 & 117.39 & 109.85 & 103.37 & & 115.96 & 118.61 & 109.95 & 103.79 & \\
\hline \multicolumn{2}{|c|}{ LSD $5 \%$} & $\begin{array}{c}\text { Salinity } \\
2.45 \\
\end{array}$ & $\begin{array}{l}\text { Bio. } \\
2.12 \\
\end{array}$ & $\begin{array}{c}\text { Inter. } \\
7.08\end{array}$ & & $\begin{array}{c}\text { Salinity } \\
3.22\end{array}$ & $\begin{array}{l}\text { Bio. } \\
3.09\end{array}$ & $\begin{array}{c}\text { Inter. } \\
7.37 \\
\end{array}$ & & \\
\hline & \multicolumn{10}{|c|}{ number of branches/plant } \\
\hline $\mathbf{0}$ & 3.64 & 3.80 & 3.28 & 2.56 & 2.32 & 3.60 & 3.84 & 3.19 & 2.61 & 3.31 \\
\hline 2.5 & 4.18 & 4.97 & 4.71 & 3.79 & 4.41 & 4.21 & 4.96 & 4.70 & 3.77 & 4.41 \\
\hline 5 & 5.87 & 6.75 & 5.18 & 4.21 & 5.50 & 5.92 & 6.77 & 5.20 & 4.23 & 5.53 \\
\hline 10 & 6.39 & 7.76 & 6.19 & 5.43 & 7.19 & 6.81 & 8.15 & 6.43 & 5.81 & 6.80 \\
\hline Mean & 5.02 & 5.82 & 4.79 & 3.85 & & 5.13 & 5.93 & 4.78 & 3.85 & \\
\hline \multicolumn{2}{|c|}{ LSD $5 \%$} & $\begin{array}{c}\text { Salinity } \\
0.81 \\
\end{array}$ & $\begin{array}{l}\text { Bio. } \\
0.66\end{array}$ & $\begin{array}{c}\text { Inter. } \\
1.62\end{array}$ & & $\begin{array}{c}\text { Salinity } \\
0.84 \\
\end{array}$ & $\begin{array}{l}\text { Bio. } \\
0.69\end{array}$ & $\begin{array}{c}\text { Inter. } \\
1.42 \\
\end{array}$ & & \\
\hline
\end{tabular}

L.S.D $_{(0.05)}=$ Least significant differences at 0.05 level of probability.

Data presented in Table (2) revealed that irrigation with saline water of EC, $8 \mathrm{dSm}^{-1}$ significantly decreased number of branches / plant form 5.02 (control) to 3.85 at $8 \mathrm{dSm}^{-1}$ and from 5.13 to 3.85 branches in the first and second seasons, respectively.

It is clear from data in Table(2) that the biofertilizers rates of 5 and $10 \mathrm{~g} /$ plant in combination with irrigation water salinity at EC $2 \mathrm{dSm}^{-1}$ gave a significant increased the number of branches / plant compared with the other treatments in both seasons. Insignificant differences were detected between previous treatments $[5 \mathrm{~g}(\mathrm{NP})+2$ $\mathrm{dSm}^{-1}$ and $\left.10 \mathrm{~g}(\mathrm{NP})+2 \mathrm{dSm}^{-1}\right]$. The highest number of branches/plant was obtained by10 g/plant of biofertilizers (NP) combined with saline water irrigation of EC, $2 \mathrm{dSm}^{-1}$ in both experimental trials (7.76 and 8.15 , respectively) as seen in Table (2). While the lowest ones resulted from applied water salinity at concentration of EC, $8 \mathrm{dSm}^{-1}$ without biofertilizers as gave 3.64 and 3.60 branches/ plant in both seasons, respectively.

The significant increase in number of branches/ plant due to applying the biofertilizers as well as to the effect of the optimum level of salinity which was suitable to increase the amount of nitrogen absorbed and also to increase the biosynthesize rate. The obtained results are in agreement with those reported by Hwang and Yoon (1995) on Chrysnthemum and Carnation plants and Osbrien and Barker (1996) on Mentha piparita plants and El-Kouny (2002) on Tomato plants.

\section{3-Number of leaves / plant}

The data presented in Table (3) indicated that the number of leaves / plant was significantly increased by using biofertilizer (NP) at any rate, compared with the untreated plant (control). The values reached to 71.99 and 70.44 leaves as a result of receiving the plants $10 \mathrm{~g} /$ plant biofertilizer compared with 22.91 and 23.17 leaves by untreated plants(control) $1 \mathrm{n}$ the first and second seasons, respectively. Generally, leaf number / plant was significantly increased by increasing the rate of biofertilizers (NP) up to10g/plant. The same results were obtained by Wange and Patil (1994) on Polianthes tuberosa L.

The data in Table(3) show that saline water of 8 $\mathrm{dSm}^{-1}$ significantly decreased the number of leaves / plant to 43.09 and 44.13 comparing with 55.34 and 54.36 for tap water, in the first and second seasons, respectively. The same results were mentioned by 
Table 3. Effect of biofertilizers, water salinity and their interaction on number of leaves/plant and dry weight of leaves(g) of Hibiscus sabdariffa, L. cv. "Sabhia 17" plants during the 2008 and 2009 seasons

\begin{tabular}{|c|c|c|c|c|c|c|c|c|c|c|}
\hline \multirow{2}{*}{$\begin{array}{l}\text { Bio. } \\
\text { rate, }\end{array}$} & \multicolumn{10}{|c|}{ Water salinity $\left(\mathrm{EC}, \mathbf{d S ~ m}^{-1}\right)$} \\
\hline & T.W & 2 & 4 & 8 & Mean & T.W & 2 & 4 & 8 & Mean \\
\hline g/plant & \multicolumn{10}{|c|}{ Number of leaves/plant } \\
\hline & \multicolumn{5}{|c|}{$\left(1^{\text {st }}\right)$ season } & \multicolumn{5}{|c|}{$\left(2^{\text {nd }}\right)$ season } \\
\hline $\mathbf{0}$ & 29.47 & 32.08 & 30.10 & 26.35 & 22.91 & 30.13 & 32.27 & 30.19 & 27.12 & 23.17 \\
\hline 2.5 & 44.76 & 46.46 & 43.29 & 37.13 & 42.91 & 45.21 & 46.62 & 44.37 & 40.00 & 44.05 \\
\hline 5 & 68.00 & 74.39 & 67.75 & 50.18 & 65.08 & 66.83 & 74.52 & 70.20 & 52.19 & 65.93 \\
\hline 10 & 79.13 & 78.63 & 71.49 & 58.70 & 71.99 & 75.27 & 77.93 & 71.35 & 57.22 & 70.44 \\
\hline Mean & 55.34 & 57.89 & 53.16 & 43.09 & & 54.36 & 57.83 & 54.03 & 44.13 & \\
\hline \multicolumn{2}{|c|}{ LSD $5 \%$} & $\begin{array}{l}\text { Salinity } \\
2.46\end{array}$ & $\begin{array}{c}\text { Bio. } \\
2.10 \\
\end{array}$ & $\begin{array}{c}\text { Inter. } \\
4.23 \\
\end{array}$ & & $\begin{array}{c}\text { Salinity } \\
1.73 \\
\end{array}$ & $\begin{array}{l}\text { Bio. } \\
1.55 \\
\end{array}$ & $\begin{array}{c}\text { Inter. } \\
3.56\end{array}$ & & \\
\hline & \multicolumn{10}{|c|}{ Dry weight of leaves(g) } \\
\hline 0 & 7.36 & 7.23 & 6.30 & 6.17 & 6.76 & 7.28 & 7.21 & 6.32 & 6.93 & 6.93 \\
\hline 2.5 & 9.78 & 10.07 & 9.72 & 9.54 & 9.77 & 9.81 & 10.12 & 9.76 & 9.52 & 9.80 \\
\hline 5 & 10.82 & 11.49 & 11.21 & 10.36 & 10.97 & 11.14 & 12.00 & 11.24 & 10.37 & 11.19 \\
\hline 10 & 12.07 & 12.87 & 12.33 & 10.59 & 11.96 & 12.16 & 12.93 & 12.35 & 10.56 & 12.00 \\
\hline Mean & 10.00 & 10.41 & 10.39 & 9.61 & & 10.10 & 10.56 & 9.92 & 9.34 & \\
\hline \multicolumn{2}{|c|}{ LSD $5 \%$} & $\begin{array}{c}\text { Salinity } \\
\mathbf{0 . 3 4}\end{array}$ & $\begin{array}{c}\text { Bio. } \\
\text { 0.23 }\end{array}$ & $\begin{array}{r}\text { Inter. } \\
0.51\end{array}$ & & $\begin{array}{c}\text { Salinity } \\
\mathbf{0 . 3 0}\end{array}$ & $\begin{array}{l}\text { Bio. } \\
\text { 0.18 }\end{array}$ & $\begin{array}{c}\text { Inter. } \\
0.46\end{array}$ & & \\
\hline
\end{tabular}

L.S.D $_{(0.05)}=$ Least significant differences at 0.05 level of probability

Mostafa (2002) on Calendula officinalis and Demorphotheca ecklonis and El-Sayed and El-Naggar (2008) on Euphorbia pluchrrima plants

For the interaction, the data in Table (3) revealed significant effects on number of leaves / plant due to applying all rates of biofertilizers with salinity treatments. The great influence of receiving the plants biofertilizers at 5 and/or $10 \mathrm{~g} /$ plant combined with EC, $2 \mathrm{dSm}^{-1}$ gave significant increase in leaves number compared with the other treatments for both experimental field .The best results were found by using biofertilizers inoculation ( $10 \mathrm{~g} /$ plant) plus saline water at $\mathrm{EC}, 2 \mathrm{dSm}^{-1}$ during the two seasons. Such treatment significantly increased the values comparing with that recorded from the other treatments (78.63 and 77.93) in both seasons, respectively. Whereas, receiving the plants the highest concentration of irrigation water salinity treatment $\left(\mathrm{EC}, 8 \mathrm{dSm}^{-1}\right)$ without biofertilizers showed the contrary action in this concern. Such treatment decreased the values to only 28.35 and 27.50 leaves in the first and second seasons, respectively.

The increase in leaves number per plant due to biofertilizer inoculation may be due to the production of adequate amounts of IAA and cytokinins, by the non- symbiotic $\mathrm{N}_{2}$-fixing bacteria; Azotobacter and Azospirillum strains used, which might be increased the surface area per unite root length and enhance root hair branching thus an increase in the nutrients uptake might occur and the biofertilizer phosphorein contains bacteria capable to solubilizing inorganic phosphate and mineralizing organic phosphate (Tarafdar and Claassen,1988 and Abd El-Fattah, 1998) which makes phosphorus available to the plants (Gaur and Ostwal, 1972 and Abo El-Nour et al. (1996). It is known that phosphate occurs in phospholipids, including those of membranes, sugar phosphates, various nucleotides and coenzymes, leading to an enhancement in nutrients absorption and biosynthetic reaction, hence the formation and initiation of new leaves; consequently, the leaves number could be increased (Xia and Xiong, 1991). The findings are in line with those observed by Attia (2000) on Lawsonia inermis, L., and El-Naggar (2010) on Narcissus tazetta, L. plants. On the other hand , the high saline water concentrations, the leaf number / plant was decreased due to inhibition of cell divition due to toxicity $\mathrm{cl}^{-1}$. These results are in agreement with those reported by El-Kouny et al.,(2004) on Hibiscus sabdariffa, $\mathrm{L}$. 


\section{4- Dry weight of leaves / plant:}

In general, the data illustrated in Table(3), showed that the differences between all rates of biofertilizers (NP) treatments in both seasons had significant effect on leaves dry weight as compared with the control treatment. Whereas the rate of biofertilizers (NP) $10 \mathrm{~g} /$ plant had the most effect on leaves dry weight with the mean of 11.96 and $12.00(\mathrm{~g})$ compared with the control (6.76 and $6.93 \mathrm{~g}$ ) in the first and second seasons, respectively. Generally, the leaves dry weight / plant was significantly increased by increasing biofertilizers (NP) levels up to10g/plant. Data in Table (3), revealed that EC levels affected on leaves dry weight. Higher EC level $8 \mathrm{dSm}^{-1}$ decreased it as compared to tap water (control) .The highest leaves dry weight resulted from the plants irrigated by saline water of EC, $2 \mathrm{dSm}^{-1}$ which gave 10.41 and $10.56 \mathrm{~g} /$ plant in both seasons, respectively.

Concerning the interaction, it could be concluded that the greatest increase in leaves dry weight was recorded with the treatment of biofertilizers $(10 \mathrm{~g} /$ plant $)$ combined with saline water at EC, $2 \mathrm{dSm}^{-1}$ with rates of increase of $74.86 \%$ and $77.61 \%$ relative to the control in both seasons, respectively (Table3). The observed significant increase in leaves dry weight as affected by applying biofertilizers inoculation could be explained by the proposed enhancement in microbial inoculants activity as which might led to promoting $\mathrm{N}$-fixation process consequently more supplied of photosynthates. The biofertilizer Phosphorein contains bacteria capable to solubilizing inorganic phosphate and mineralizing organic phosphate (Abd El-Fattah, 1998 and Tarafdar and Claassen,1988) which makes phosphorus available to the plants (Abo El-Nour et al. 1996; Gaur and Ostwal, 1972 and Krasilnikov, 1972). It is known that phosphate occurs in phospholipids, including those of membranes, sugar phosphates, various nucleotides and co-enzymes, leading to an enhancement in nutrients absorption and accumulation of synthesates (Xia and Xiong, 1991). Whereas, the contrary action on the leaves dry weight was observed on the obtained values resulting from receiving the plants EC, $2 \mathrm{dSm}^{-1}$ irrigation saline water without biofertilizer, as the values were decreased to only 8.17 and $7.93 \mathrm{~g}$ in the first and second seasons, respectively. These results may be due to the toxic effects of $\mathrm{Na}$ and $\mathrm{Ca}$ ions accumulated in the cytoplasm of root cells, besides the reduction of the total water uptake by root leading to a reduction in leaf cells division and elongation, consequently the leaves dry matter could be decreased. The findings are in line with those observed by Nofal et al., (1983) on Adhatoda vasica and Thuja orientalis and Attia (2000) on Lawsonia inermis, L., plants.

\section{II - Yield characteristics}

\section{1- Number of fruits / plant}

Data in Table (4),showed that application of biofertilizers (NP) was significantly effective on the number of fruits/plant of Hibiscus sabdariffa, L. c v. "Sabahia 17" plants .Generally, the greatest number of fruits /plant was obtained by using $10 \mathrm{~g}$ biofertilizers (NP). Whereas, the number of fruits/plant was significantly increased by increasing the rate of biofertilizers (NP) up to $10 \mathrm{~g} /$ plant Such treatment increased the values to 18.45 and 18.73 in both seasons, respectively.

It is evident from the obtained data in Table (4) clear that the number of fruits/ plant decreased with increasing of EC concentration, except EC, $2 \mathrm{dSm}^{-1}$ in both seasons. While the lowest ones resulted from applied water $8 \mathrm{dSm}^{-1} \mathrm{EC}$ as gave 10.89 and 10.86 in the two growing seasons, respectively.

Data in Table (4), show the increment on the number of fruits/ plant due to using bofertilizer (NP) at 5 and/or $10 \mathrm{~g} /$ plant combined with suitable level of EC, $2 \mathrm{dSm}^{-}$ ${ }^{1}$ water salinity irrigations resulted in the greatest fruits number/plant (20.91 and 19.79) for the first treatment $\left(5 \mathrm{~g} /\right.$ plant bio. $\left.+2 \mathrm{dSm}^{-1} \mathrm{EC}\right)$ and 23.76 and 24.31 flowers for the second $\left(10 \mathrm{~g} /\right.$ plant bio. $+2 \mathrm{dSm}^{-1}$ EC) in both seasons, respectively. Table (4). Meanwhile, the contrary action which was a result of receiving the plants EC, $8 \mathrm{dSm}^{-}$irrigation treatment without any rate of biofertilizer. It decreased the values to only 6.22 and 6.17 fruits in the first and second seasons, respectively. The observed significant increase in number of fruits per plant as a result of applying the biofertilizer could be related to the increase in leaves number per plant, which in turn supplied more photosynthates and related to an improvement of the hydrophysical and chemical characteristics of the soil, which would lead to increase the availability and uptake of nutrients elements such as nitrogen and phosphorus. On the other hand, the observed decreased in this respect as a result of using high level of salinity up to $\mathrm{EC}, 8 \mathrm{dSm}^{-1}$ may be due to the presence and accumulation of toxic ions $\left(\mathrm{Na}^{+}\right.$and $\mathrm{Cl}^{-}$) in the plant tissue which may raise the respiration and reduced the photosynthetic process and leading to a poor production of flowers number. These results are in agreement with those of Holcomb (1984) on Tagetes $s p$ and Wange and Patil (1994) on Polianthes tuberose.

\section{3- Fresh and dry weights of fruits/ plant .}

Generally, the heaviest of fresh and dry weights of fruits / plant was obtained by using biofertilizer (NP) at $10 \mathrm{~g} / \mathrm{plant}$. The values reached to 70.75 and 70.69 F.F.W. and 5.52 and 5.44 F.D.W compared with the 
Table 4. Effect of biofertilizers, water salinity and their interaction on number of fruits/plant, fresh and dry weight of fruits(g) of Hibiscus sabdariffa, L. cv. "Sabhia 17" plants during the 2008 and 2009 seasons

\begin{tabular}{|c|c|c|c|c|c|c|c|c|c|c|}
\hline \multirow{3}{*}{$\begin{array}{c}\text { Bio. } \\
\text { rate, } \\
\text { g/plant }\end{array}$} & \multicolumn{10}{|c|}{ Water salinity ( $\mathrm{EC}, \mathrm{dS} \mathrm{m}^{-1}$ ) } \\
\hline & T.W & 2 & 4 & 8 & Mean & T.W & 2 & 4 & 8 & Mean \\
\hline & \multicolumn{10}{|c|}{ number of fruits/ plant } \\
\hline & \multicolumn{5}{|c|}{$\left(1^{\text {st }}\right)$ season } & \multicolumn{5}{|c|}{$\left(2^{\text {nd }}\right)$ season } \\
\hline $\mathbf{0}$ & 7.26 & 9.75 & 7.33 & 6.22 & 7.64 & 7.15 & 9.88 & 7.20 & 6.17 & 7.60 \\
\hline 2.5 & 13.28 & 16.97 & 14.69 & 11.67 & 14.15 & 13.00 & 17.09 & 14.72 & 11.24 & 14.01 \\
\hline 5 & 15.54 & 20.91 & 15.87 & 12.39 & 16.17 & 15.29 & 19.79 & 15.88 & 13.20 & 16.04 \\
\hline 10 & 18.42 & 23.76 & 18.36 & 13.27 & 18.45 & 18.59 & 24.31 & 19.17 & 12.85 & 18.73 \\
\hline Mean & 13.62 & 17.85 & 14.06 & 10.89 & & 13.51 & 17.77 & 14.24 & 10.86 & \\
\hline \multicolumn{2}{|c|}{ LSD 5\% } & $\begin{array}{l}\text { Salinity } \\
\mathbf{3 . 1 3} \\
\end{array}$ & $\begin{array}{l}\text { Bio. } \\
2.34 \\
\end{array}$ & $\begin{array}{l}\text { Inter. } \\
6.29 \\
\end{array}$ & & $\begin{array}{c}\text { Salinity } \\
2.68 \\
\end{array}$ & $\begin{array}{l}\text { Bio. } \\
2.12 \\
\end{array}$ & $\begin{array}{l}\text { Inter. } \\
5.74\end{array}$ & & \\
\hline & \multicolumn{10}{|c|}{ fresh weight of fruits $(\mathrm{g})$} \\
\hline $\mathbf{0}$ & 30.27 & 43.85 & 36.39 & 27.18 & 32.42 & 29.73 & 44.00 & 36.38 & 26.84 & 34.24 \\
\hline 2.5 & 55.35 & 67.43 & 57.26 & 49.32 & 57.34 & 55.12 & 67.42 & 57.30 & 49.30 & 57.28 \\
\hline 5 & 61.87 & 73.89 & 64.92 & 54.10 & 63.69 & 60.86 & 73.88 & 64.90 & 54.13 & 63.44 \\
\hline 10 & 68.49 & 82.21 & 69.45 & 62.85 & 70.75 & 68.52 & 82.78 & 69.48 & 61.99 & 70.69 \\
\hline Mean & 53.99 & 66.84 & 57.00 & 48.36 & & 53.56 & 67.02 & 57.01 & 48.06 & \\
\hline \multicolumn{2}{|c|}{ LSD 5\% } & $\begin{array}{l}\text { Salinity } \\
5.22 \\
\end{array}$ & $\begin{array}{c}\text { Bio. } \\
3.46 \\
\end{array}$ & $\begin{array}{c}\text { Inter. } \\
6.53 \\
\end{array}$ & & $\begin{array}{c}\text { Salinity } \\
\mathbf{4 . 8 3} \\
\end{array}$ & $\begin{array}{l}\text { Bio. } \\
3.11 \\
\end{array}$ & $\begin{array}{c}\text { Inter. } \\
5.77\end{array}$ & & \\
\hline & \multicolumn{10}{|c|}{ dry weight of fruits (g) } \\
\hline $\mathbf{0}$ & 3.33 & 3.68 & 3.37 & 3.09 & 3.37 & 3.25 & 3.72 & 3.38 & 3.00 & 3.34 \\
\hline 2.5 & 4.21 & 6.19 & 3.98 & 3.55 & 4.48 & 4.22 & 6.38 & 4.01 & 3.49 & 4.52 \\
\hline 5 & 5.25 & 7.37 & 5.46 & 4.27 & 5.59 & 5.32 & 7.39 & 4.24 & 4.28 & 5.31 \\
\hline 10 & 5.43 & 7.98 & 5.49 & 3.19 & 5.52 & 5.45 & 7.96 & 5.20 & 3.16 & 5.44 \\
\hline Mean & 4.55 & 6.30 & 4.57 & 3.52 & & 4.56 & 6.36 & 4.21 & 3.48 & \\
\hline \multicolumn{2}{|c|}{ LSD $5 \%$} & \begin{tabular}{l|} 
Salinity \\
0.77 \\
\end{tabular} & $\begin{array}{l}\text { Bio. } \\
0.59 \\
\end{array}$ & $\begin{array}{l}\text { Inter. } \\
1.21 \\
\end{array}$ & & $\begin{array}{c}\text { Salinity } \\
0.76 \\
\end{array}$ & $\begin{array}{l}\text { Bio. } \\
\text { 0.54 }\end{array}$ & $\begin{array}{c}\text { Inter. } \\
1.17\end{array}$ & & \\
\hline
\end{tabular}

L.S.D $(0.05)=$ Least significant differences at 0.05 level of probability. control in the two growing season, respectively. Table (4). Fresh and dry weight of fruits / plant were significantly increased by using biofertilizers (NP) up to $10 \mathrm{~g} /$ plant.

Data of the two seasons in Table (4) indicated that the total fresh and dry weights of fruits / plant were significantly decreased by using saline water irrigation of EC, 4 or $8 \mathrm{dSm}^{-1}$ compared with the control during the two seasons.

Concerning the interaction, it could be concluded that receiving the plants the highest rate of biofertilizerS (NP) with salinity treatment at EC, $2 \mathrm{dSm}^{-1}$ was the best treatment for increasing fresh and dry weights of fruits / plant for both seasons. The significant increase in fruits weight due to applying biofertilizers at low salinity on increasing the vegetative growth of the used plants

leading to more accumulation of biosynthesizes, thus the fruits weight could be increased. These results are in agreement with these obtained El-Kouny et al., (2004) on Hibiscus sabdariffa, L. plants.

\section{III - Chemical analysis of plants}

\section{1- Total anthocyanine pigment (\%) and vitamin $C$} concentration(mg/100gm) of sepales

Data in Table (5) showed that the anthocyanine pigment $\%$ and vitamin $\mathrm{C}(\mathrm{mg} / 100 \mathrm{gm})$ of sepals increased gradually with increasing biofertilizers rates in the two seasons. The highest value of anthocyanine\% and Vitamin C was found in plants grown at rate of $10 \mathrm{~g} / \mathrm{plant}$ which equal $1.82,1.80 \%$ anthocyanine and $10.77,10.82 \mathrm{mg} / 100 \mathrm{gm}$ of vitamin $\mathrm{C}$ the first and second seasons as compared with the other treatments during the two growing seasons. 
Table 5. Effect of biofertilizers, water salinity and their interaction on anthocyanin (\%), vitamin $\mathrm{C}(\mathrm{mg} / 100 \mathrm{~g}$ of sepals D.W) and total chlorophylls content of leaves (mg/100 $\mathrm{g} \mathrm{F}$.W.) of Hibiscus sabdariffa, L. cv. "Sabhia 17" plants during the 2008 and 2009 seasons

\begin{tabular}{|c|c|c|c|c|c|c|c|c|c|c|}
\hline \multirow{2}{*}{$\begin{array}{l}\text { Bio. } \\
\text { rate, }\end{array}$} & \multicolumn{10}{|c|}{ Water salinity $\left(\mathrm{EC}, \mathrm{dS} \mathrm{m}^{-1}\right)$} \\
\hline & T.W & 2 & 4 & 8 & Mean & T.W & 2 & 4 & 8 & Mean \\
\hline g/plant & \multicolumn{10}{|c|}{ Anthocyanin (\%) } \\
\hline & \multicolumn{5}{|c|}{$\left(1^{\text {st }}\right)$ season } & \multicolumn{5}{|c|}{$\left(2^{\text {nd }}\right)$ season } \\
\hline $\mathbf{0}$ & 1.10 & 1.41 & 1.20 & 1.12 & 1.21 & 1.13 & 1.46 & 1.16 & 1.00 & 1.19 \\
\hline 2.5 & 1.22 & 1.59 & 1.44 & 1.31 & 1.39 & 1.29 & 1.55 & 1.48 & 1.36 & 1.42 \\
\hline 5 & 1.43 & 2.13 & 1.70 & 1.51 & 1.69 & 1.48 & 2.17 & 1.72 & 1.53 & 1.72 \\
\hline 10 & 1.50 & 2.41 & 1.79 & 1.59 & 1.82 & 1.53 & 2.38 & 1.77 & 1.53 & 1.80 \\
\hline Mean & 1.31 & 1.88 & 1.53 & 1.38 & & 1.36 & 1.89 & 1.53 & 1.35 & \\
\hline \multicolumn{2}{|c|}{ LSD $5 \%$} & $\begin{array}{l}\text { Salinity } \\
\text { 0.36 } \\
\end{array}$ & $\begin{array}{l}\text { Bio. } \\
0.21\end{array}$ & $\begin{array}{l}\text { Inter. } \\
1.10\end{array}$ & & $\begin{array}{c}\text { Salinity } \\
0.39 \\
\end{array}$ & $\begin{array}{l}\text { Bio. } \\
0.21 \\
\end{array}$ & $\begin{array}{l}\text { Inter. } \\
1.12\end{array}$ & & \\
\hline & \multicolumn{10}{|c|}{ Vitamin C ( mg/100gof sepals D.W) } \\
\hline $\mathbf{0}$ & 5.29 & 5.52 & 5.27 & 4.71 & 5.20 & 5.32 & 5.55 & 5.23 & 5.01 & 5.28 \\
\hline 2.5 & 5.87 & 8.92 & 8.36 & 7.11 & 7.56 & 5.91 & 8.87 & 8.39 & 7.18 & 7.59 \\
\hline 5 & 6.90 & 11.78 & 10.43 & 9.26 & 9.59 & 7.27 & 11.82 & 10.47 & 9.29 & 9.71 \\
\hline 10 & 8.94 & 12.20 & 12.00 & 9.93 & 10.77 & 9.02 & 12.27 & 12.06 & 9.90 & 10.82 \\
\hline Mean & 6.75 & 9.60 & 9.01 & 7.75 & & 6.86 & 9.63 & 9.01 & 7.84 & \\
\hline \multicolumn{2}{|c|}{ LSD 5\% } & $\begin{array}{l}\text { Salinity } \\
2.32 \\
\end{array}$ & $\begin{array}{l}\text { Bio. } \\
1.78\end{array}$ & $\begin{array}{l}\text { Inter. } \\
\mathbf{2 . 8 6}\end{array}$ & & $\begin{array}{c}\text { Salinity } \\
2.16 \\
\end{array}$ & $\begin{array}{l}\text { Bio. } \\
1.63 \\
\end{array}$ & $\begin{array}{l}\text { Inter. } \\
2.55\end{array}$ & & \\
\hline & \multicolumn{10}{|c|}{ Total chlorophyll (mg/100 g F.W.) } \\
\hline $\mathbf{0}$ & 122.18 & 124.38 & 120.73 & 120.00 & 121.82 & 121.99 & 124.85 & 121.62 & 120.11 & 122.14 \\
\hline 2.5 & 131.52 & 136.49 & 132.02 & 131.19 & 132.80 & 133.00 & 136.15 & 132.28 & 130.17 & 132.90 \\
\hline 5 & 169.30 & 189.37 & 183.84 & 176.33 & 179.71 & 168.81 & 191.23 & 184.44 & 176.72 & 180.03 \\
\hline 10 & 173.42 & 193.63 & 187.75 & 176.98 & 182.94 & 172.32 & 194.27 & 187.10 & 177.31 & 182.75 \\
\hline Mean & 149.10 & 160.97 & 156.08 & 151.12 & & 149.03 & 161.37 & 156.11 & 151.08 & \\
\hline \multicolumn{2}{|c|}{ LSD 5\% } & $\begin{array}{l}\text { Salinity } \\
4.32 \\
\end{array}$ & $\begin{array}{l}\text { Bio. } \\
3.78\end{array}$ & $\begin{array}{l}\text { Inter. } \\
4.86 \\
\end{array}$ & & $\begin{array}{c}\text { Salinity } \\
\mathbf{3 . 1 6} \\
\end{array}$ & $\begin{array}{l}\text { Bio. } \\
2.09\end{array}$ & $\begin{array}{l}\text { Inter. } \\
\mathbf{3 . 6 3}\end{array}$ & & \\
\hline
\end{tabular}

L.S.D $_{(0.05)}=$ Least significant differences at 0.05 level of probability.

Meanwhile, total anthocyanine pigment and vitamin $\mathrm{C}$ concentration decreased with increasing salinity concentration in the irrigation water during the two successive seasons. except EC $2 \mathrm{dSm}^{-1}$ as compared to control ( tap water) in the two seasons. The treatment of EC $2 \mathrm{dSm}^{-1}$ gave the maximum of anthocyanine \% ( 1.88 and $1.89 \%)$ and vitamin $\mathrm{C}(9.60$ and 9.63 $\mathrm{mg} / 100 \mathrm{gm})$ in the first and second seasons, respectively. Whereas, applying irrigation treatment at $8 \mathrm{dSm}^{-1}$ recorded the lowest values. Such treatment decreased anthocyanine \% to only 1.38 and $1.35 \%$ in both seasons, respectively, and decreased Vitamin $\mathrm{C}$ to 7.75 and $7.84 \mathrm{mg} / 100 \mathrm{gm}$ in the first and second seasona , respectively.
For the interaction, Table (5) showed that the concentration of anthocyanine pigment $\%$ and vitamin $\mathrm{C}$ $(\mathrm{mg} / 100 \mathrm{gm})$ of sepals increased significantly with increasing biofertilizers rates with $\mathrm{EC}, 2 \mathrm{dSm}^{-1}$ of the saline irrigation water. However, the highest salinity treatment, $\left(\mathrm{EC}, 8 \mathrm{dSm}^{-1}\right.$ ) in combination with any of biofertilizers rates minimized these parameters to the lowest degree as compared to the other saline water treatments. However, the EC $2 \mathrm{dSm}^{-1}$ salinity was superior in enhancing the anthocyanine and vitamin $\mathrm{C}$ concentration to a greater degree which maximized upon adding the biofertilizers treatment at a rate of $10 \mathrm{~g} / \mathrm{plant}$. Such treatment increased Anthocyanine pigment to 2.41 and $2.38 \%$ and increased vitamin $\mathrm{C}$ to 12.20 and 12.06 $\mathrm{mg} / 100 \mathrm{gm}$ in the first and second seasons, respectively. 
The results could be attributed to enhancing effect of biofertilizers inoculation combined with the suitable levels of water salinity irrigation directly or indirectly, on increasing availability and absorption of the essential nutrient elements, especially iron $\left(\mathrm{Fe}^{2+}\right)$, magnesium $\left(\mathrm{Mg}^{2+}\right)$, nitrogen $\left(\mathrm{NH}_{4}{ }^{2+}\right)$, and soluble phosphorus, which are necessary in synthesis of phosoholipids of membrane, sugar as well as nucleotides and co-enzymes. Similar trend of results was found by Moor (2000) with Salivia splendens plants

\section{2- Total chlorophylls content of Leaves:}

As shown in Table (5) total chlorophylls content seemed to be increased with all biofertilizer treatments compared with control. Generally, the total chlorophylls was significantly increased by using different rates of biofertilizers(NP) up to $10 \mathrm{~g} / \mathrm{plant}$. The highest values of chlorophylls were observed with the treatment of $10 \mathrm{~g} /$ plant ( 182.94 and $182.75 \mathrm{mg} / 100 \mathrm{~g} \mathrm{L.F.W.)} \mathrm{in} \mathrm{both}$ seasons, respectively followed by the treatments of $5 \mathrm{~g}$ /plant as giving 179.71 and $180.03 \mathrm{mg} / 100 \mathrm{~g} \mathrm{L.F.W.} \mathrm{for}$ both seasons, respectively and no significant The differences between the two treatments namely 5 and 10 $\mathrm{g} /$ plant were not significant during the two growing seasons. In addition, Applying saline water at the rate EC 4 and $8 \mathrm{dSm}^{-1}$ reduced the total chlorophylls content as compared with the control. Whereas, the lowest values were obtained as a result of EC $8 \mathrm{dSm}^{-}$ ${ }^{1}$.These decreased of the total chlorophylls to 151.12 and $151.08 \mathrm{mg} / 100 \mathrm{~g}$ L.F.W. in the first and second seasons, respectively. These results are somewhat like that observed by EL-sayed (2003) on Murraya exotica.

Concerning the interaction, it could be concluded that receiving the plants $10 \mathrm{~g} /$ plant biofertilizers with EC $2 \mathrm{dSm}^{-1}$ were the best treatments for increasing the total chlorophylls in both seasons. Such treatment increased the values to 193.63 and $194.27 \mathrm{mg} / 100 \mathrm{~g}$ L.F.W. in the first and second seasons, respectively ( Table 5).

The significant increase in total chlorophylls content as a result of biofertilizers inoculation with low concentrations of salinity could be due to increasing the availability of nitrogen, consequently increasing its absorption by the plant. It is well known that nitrogen is present in chlorophyll molecule. The results are in accordance with those obtained by El-Gamal (1996) who mentioned that mixed biofertilizers (Azotobacter, Azospirillum and Klebsiella) significantly increased leaf chlorophylls content in potato plants. Reddy et al., (2003) reported that total chlorophylls increased considerably in mulberry varieties with Azotobacter inoculation. Also, Abou El-Khashab (2003) revealed that inoculation olive seedlings cv. "Picual" with Azotobacter and Azospirillum highly influenced chlorophyll pigments.

\section{3- Nutrients Contents of Leaves:}

\section{1- Nitrogen and phosphorus contents (\%):}

$\mathrm{N}$ and $\mathrm{P}$ contents in leaves of Hibiscus sabdariffa, $\mathrm{L}$. cv. "Sabhia 17", as shown in Table(6), were significantly increased as a result of using biofertilizers treatment as compared with control. The highest significant increases of $\mathrm{N}$ and $\mathrm{P} \%$ were found in plants at $10 \mathrm{~g} /$ plant biofertilizers in both seasons. A gradual decrease of $\mathrm{N}$ and $\mathrm{P}$ contents was recorded with increasing salinity concentration in the irrigation water during the two successive seasons.

Concerning the interaction between biofertilizer rates and saline water, the obtained results indicated that, application of the highest biofertilizer rate $(10 \mathrm{~g})$ to plants growing under EC, $2 \mathrm{dSm}^{-1}$ resulted in the highest $\mathrm{N}$ and $\mathrm{P}$ contents in the leaves. These results may be due to the effect of biofertilizers treatments, consequently increasing the absorbed amount of $\mathrm{N}$, especially under the lower values of salinity. On the other hand, the highest level of salinity may reduce the availability of elements and growth of roots, resulted in a lower $\mathrm{N}$ content. Similar trend of results was reported by Mostafa (2002) on Calendula officinalis and Demorphotheca ecklonis.

\section{2- Potassium content (\%):}

The results indicated that the biofertilizer rates significantly affected potassium content in the leaves. Whereas, the highest $\mathrm{K}$ value was recorded with using $10 \mathrm{~g}$ biofertilizer $1.80 \%$ )for the two seasons followed by $5 \mathrm{~g}$ biofertilizer (1.62and 1.64\%), compared to the control in the first and second seasons, respectively. This result agrees with that obtained by El- Naggar 2010 on Narcissus tazetta, L. plants .

The data showed that salinity negatively affected $\mathrm{K}$ $\%$ of leaves in the two seasons. As well as K\% decreased gradually and continuously with increasing of water salinity concentration. $\mathrm{K}$ content decline from 1.46 (control) to 1.44 and $1.35 \%$ at EC,4and $8 \mathrm{dSm}^{-1}$ and from 1.47 to 1.46 and $1.34 \%$ in the first and second seasons, respectively. Concerning the interaction, the highest $\mathrm{K}$ content in the leaves was observed with plants receiving $10 \mathrm{~g}$ biofertilizer combined with $\mathrm{EC}, 2 \mathrm{dSm}^{-1}$, as compared with other treatments. Such treatment increased the values to 1.92 and $1.98 \%$ in both seasons, respectively. The previous result may be due to the presence of high rate of biofertilizers in the rooting medium, consequently the plant could absorb a high amount of it besides, the highly mobility and translocation of $\mathrm{K}$ in the plant tissue led to increase it . similar trend of results was stated by Mostafa (2002) on Calendula officinalis and Demorphotheca ecklonis. 
Table 6. Effect of biofertilizers, water salinity and their interaction on $N, P$ and $K$ contents of content of leaves (\%)of Hibiscus sabdariffa, L. cv. "Sabhia 17" plants during the 2008 and 2009 seasons

\begin{tabular}{|c|c|c|c|c|c|c|c|c|c|c|}
\hline \multirow{2}{*}{$\begin{array}{l}\text { Bio. } \\
\text { rate, }\end{array}$} & \multicolumn{10}{|c|}{ Water salinity ( $\left.\mathrm{EC}, \mathrm{dS} \mathrm{m}^{-1}\right)$} \\
\hline & T.W & 2 & 4 & 8 & Mean & T.W & 2 & 4 & 8 & Mean \\
\hline \multirow[t]{2}{*}{ g/plant } & \multicolumn{10}{|c|}{$\mathbf{N}(\%)$} \\
\hline & \multicolumn{5}{|c|}{$\left(1^{\text {st }}\right)$ season } & \multicolumn{5}{|c|}{$\left(2^{\text {nd }}\right)$ season } \\
\hline $\mathbf{0}$ & 1.46 & 1.37 & 1.26 & 1.09 & 1.29 & 1.53 & 1.39 & 1.27 & 1.10 & 1.32 \\
\hline 2.5 & 1.66 & 1.71 & 1.60 & 1.51 & 1.62 & 1.65 & 1.74 & 1.61 & 1.53 & 1.63 \\
\hline 5 & 2.00 & 2.25 & 2.08 & 1.74 & 2.08 & 2.04 & 2.31 & 2.12 & 1.77 & 2.06 \\
\hline 10 & 2.43 & 2.65 & 2.33 & 2.18 & 2.39 & 2.47 & 2.70 & 2.35 & 2.14 & 2.41 \\
\hline Mean & 1.89 & 1.99 & 1.82 & 1.63 & & 1.92 & 2.03 & 1.84 & 1.63 & \\
\hline \multicolumn{2}{|c|}{ LSD 5\% } & $\begin{array}{l}\text { Salinity } \\
\text { 0.36 } \\
\end{array}$ & $\begin{array}{l}\text { Bio. } \\
\text { 0.21 }\end{array}$ & $\begin{array}{l}\text { Inter. } \\
1.10\end{array}$ & & $\begin{array}{c}\text { Salinity } \\
0.39 \\
\end{array}$ & $\begin{array}{l}\text { Bio. } \\
0.21\end{array}$ & $\begin{array}{l}\text { Inter. } \\
1.12\end{array}$ & & \\
\hline & \multicolumn{10}{|c|}{$P(\%)$} \\
\hline $\mathbf{0}$ & 0.152 & 0.149 & 0.132 & 0.123 & 0.139 & 0.160 & 0.155 & 0.147 & 0.126 & 0.147 \\
\hline 2.5 & 0.177 & 0.183 & 0.180 & 0.172 & 0.178 & 0.181 & 0.186 & 0.180 & 0.173 & 0.180 \\
\hline 5 & 0.205 & 0.224 & 0.217 & 0.195 & 0.201 & 0.210 & 0.231 & 0.220 & 0.197 & 0.214 \\
\hline 10 & 0.239 & 0.269 & 0.245 & 0.213 & 0.241 & 0.244 & 0.272 & 0.256 & 0.216 & 0.247 \\
\hline Mean & 0.193 & 0.206 & 0.193 & 0.176 & & 0.199 & 0.211 & 0.201 & 0.178 & \\
\hline \multicolumn{2}{|c|}{ LSD $5 \%$} & $\begin{array}{l}\text { Salinity } \\
\mathbf{0 . 0 2 3} \\
\end{array}$ & $\begin{array}{r}\text { Bio. } \\
\mathbf{0 . 0 3 1} \\
\end{array}$ & $\begin{array}{l}\text { Inter. } \\
\mathbf{0 . 0 4 2}\end{array}$ & & $\begin{array}{c}\text { Salinity } \\
0.019 \\
\end{array}$ & \begin{tabular}{|l} 
Bio. \\
0.011 \\
\end{tabular} & $\begin{array}{l}\text { Inter. } \\
\mathbf{0 . 0 2 6}\end{array}$ & & \\
\hline & \multicolumn{10}{|c|}{$\mathbf{K}(\%)$} \\
\hline $\mathbf{0}$ & 1.16 & 1.19 & 1.11 & 1.02 & 1.12 & 1.21 & 1.18 & 1.13 & 1.00 & 1.13 \\
\hline 2.5 & 1.32 & 1.39 & 1.24 & 1.20 & 1.29 & 1.36 & 1.41 & 1.22 & 1.19 & 1.29 \\
\hline 5 & 1.57 & 1.76 & 1.63 & 1.51 & 1.62 & 1.56 & 1.79 & 1.65 & 1.55 & 1.64 \\
\hline 10 & 1.79 & 1.92 & 1.80 & 1.69 & 1.80 & 1.77 & 1.98 & 1.83 & 1.63 & 1.80 \\
\hline Mean & 1.46 & 1.56 & 1.44 & 1.35 & & 1.47 & 1.59 & 1.46 & 1.34 & \\
\hline \multicolumn{2}{|c|}{ LSD $5 \%$} & $\begin{array}{l}\text { Salinity } \\
0.09 \\
\end{array}$ & $\begin{array}{l}\text { Bio. } \\
\text { 0.07 }\end{array}$ & $\begin{array}{l}\text { Inter. } \\
0.12\end{array}$ & & $\begin{array}{c}\text { Salinity } \\
0.09 \\
\end{array}$ & $\begin{array}{l}\text { Bio. } \\
\text { 0.08 }\end{array}$ & $\begin{array}{c}\text { Inter. } \\
0.13\end{array}$ & & \\
\hline
\end{tabular}

L.S.D $(0.05)=$ Least significant differences at 0.05 level of probability.

El-Naggar and Hedia (2005) on Narcissus tazetta,L. and El-Sayed and El-Naggar (2008) on Euphorbia pluchrrima plants.

\section{IV- Chemical analysis of soil}

\section{1- Soil EC, pH and SAR}

The obtained data in Table (7) showed that $\mathrm{pH}, \mathrm{EC}$ and SAR of growing medium decreased gradually with increasing of biofertilizers application in the two seasons. The lowest values of $\mathrm{pH}, \mathrm{EC}$ and SAR of soil was recorded in the treatment of $10 \mathrm{~g}$ which equal 7.67 , 3.36 and 8.66 in the first season and 7.72, 2.44 and 8.70 in the second season compared to the control treatment in both seasons. According to data in Table (7) it is obvious that $\mathrm{pH}, \mathrm{EC}$ and SAR of soil increased with increasing of salinity concentration in irrigation water in the two seasons. The highest value was recorded in soil in the treatment of EC $8 \mathrm{dSm}^{-1}$.

Concerning the interaction, the data illustrates that water salinity at any level $\left(\mathrm{EC}, 2\right.$ to $8 \mathrm{dSm}^{-1}$,) the soil $\mathrm{pH}$ ,EC and SAR were significantly decreased with increasing biofertilizers rates $(5-10 \mathrm{~g} / \mathrm{plant}$,range). The low rate of biofertilizer was effective on decreasing soil $\mathrm{pH}, \mathrm{EC}$ and SAR at water salinity of EC, $2 \mathrm{dSm}^{-1}$ than $8 \mathrm{dSm}^{-1}$, whereas the high rate of biofertiliers was more effective on decreasing the soil $\mathrm{pH}, \mathrm{EC}$ and SAR within each concentration of water salinity in the two seasons Table (7). The reduction in these parameters of soil may be attributed to the formation of the organic acids (Shaban and Helmy,2006). The greater reduction in SAR at the highest biofertilizers rate clearly indicates 
Table 7. Effect of biofertilizers, water salinity and their interaction on $\mathrm{pH}, \mathrm{EC}$ and SAR in the growing medium of Hibiscus sabdariffa, L. cv. "Sabhia 17" leaves during the 2008 and 2009 seasons

\begin{tabular}{|c|c|c|c|c|c|c|c|c|c|c|}
\hline \multirow{2}{*}{$\begin{array}{c}\text { Bio. } \\
\text { rate, }\end{array}$} & \multicolumn{10}{|c|}{ Water salinity ( $\left.\mathrm{EC}, \mathbf{d S ~ m}^{-1}\right)$} \\
\hline & T.W & 4 & 8 & 12 & Mean & T.W & 4 & 8 & 12 & Mean \\
\hline $\mathrm{m}^{3} \mathrm{fed}^{-1}$ & \multicolumn{10}{|c|}{ pH } \\
\hline & \multicolumn{5}{|c|}{$\left(1^{\text {st }}\right)$ season } & \multicolumn{5}{|c|}{$\left(2^{\text {nd }}\right)$ season } \\
\hline $\mathbf{0}$ & 8.10 & 8.10 & 8.20 & 8.30 & 8.17 & 8.10 & 8.15 & 8.20 & 8.30 & 8.19 \\
\hline 2.5 & 7.90 & 8.10 & 8.15 & 8.25 & 8.10 & 7.85 & 8.15 & 8.15 & 8.25 & 8.10 \\
\hline 5 & 7.75 & 7.80 & 7.90 & 7.90 & 7.84 & 7.75 & 7.75 & 7.80 & 7. 90 & 7.80 \\
\hline 10 & 7.60 & 7.65 & 7.70 & 7.75 & 7.67 & 7.70 & 7.65 & 7.75 & 7.80 & 7.72 \\
\hline Mean & 7.84 & 7.91 & 7.99 & 8.05 & & 7.85 & 7.92 & 7.97 & 8.06 & \\
\hline \multicolumn{2}{|c|}{ LSD 5\% } & $\begin{array}{l}\text { Salinity } \\
\text { 0.10 } \\
\end{array}$ & $\begin{array}{l}\text { Bio. } \\
0.07\end{array}$ & $\begin{array}{l}\text { Inter. } \\
0.13\end{array}$ & & $\begin{array}{c}\text { Salinity } \\
0.10 \\
\end{array}$ & $\begin{array}{l}\text { Bio. } \\
\text { 0.07 }\end{array}$ & $\begin{array}{c}\text { Inter. } \\
0.13\end{array}$ & & \\
\hline & \multicolumn{10}{|c|}{$\operatorname{EC}\left(\mathrm{dS} \mathrm{m}^{-1}\right)$} \\
\hline $\mathbf{0}$ & 2.50 & 2.59 & 3.65 & 4.18 & 3.23 & 2.50 & 2.63 & 3.70 & 4.10 & 3.23 \\
\hline 2.5 & 2.22 & 2.31 & 3.32 & 4.08 & 2.98 & 2.20 & 2.36 & 3.40 & 3.87 & 2.96 \\
\hline 5 & 2.00 & 2.20 & 2.74 & 3.42 & 2.59 & 2.00 & 2.20 & 2.93 & 3.48 & 2.65 \\
\hline 10 & 1.82 & 1.99 & 2.55 & 3.10 & 3.36 & 1.81 & 2.07 & 2.67 & 3.21 & 2.44 \\
\hline Mean & 2.13 & 2.27 & 3.06 & 3.69 & & 2.13 & 2.31 & 3.17 & 3.66 & \\
\hline \multicolumn{2}{|c|}{ LSD 5\% } & $\begin{array}{l}\text { Salinity } \\
0.17 \\
\end{array}$ & $\begin{array}{l}\text { Bio. } \\
0.22 \\
\end{array}$ & $\begin{array}{l}\text { Inter. } \\
0.38\end{array}$ & & $\begin{array}{c}\text { Salinity } \\
0.17 \\
\end{array}$ & $\begin{array}{l}\text { Bio. } \\
0.21 \\
\end{array}$ & $\begin{array}{c}\text { Inter. } \\
0.36\end{array}$ & & \\
\hline & \multicolumn{10}{|c|}{ SAR } \\
\hline $\mathbf{0}$ & 8.75 & 11.48 & 12.96 & 15.99 & 11.54 & 8.69 & 9.65 & 12.77 & 15.87 & 11.74 \\
\hline 2.5 & 7.87 & 9.75 & 12.11 & 14.32 & 11.01 & 7.88 & 9.67 & 11.98 & 14.27 & 10.95 \\
\hline 5 & 7.03 & 9.15 & 11.73 & 12.26 & 10.04 & 7.00 & 8.84 & 11.50 & 12.20 & 9.88 \\
\hline 10 & 6.15 & 7.22 & 10.20 & 11.08 & 8.66 & 6.17 & 7.14 & 10.13 & 11.36 & 8.70 \\
\hline Mean & 7.45 & 9.40 & 11.75 & 13.41 & & 7.43 & 8.82 & 11.59 & 13.42 & \\
\hline \multicolumn{2}{|c|}{ LSD $5 \%$} & $\begin{array}{l}\text { Salinity } \\
1.24 \\
\end{array}$ & $\begin{array}{l}\text { Bio. } \\
\text { 0.33 }\end{array}$ & $\begin{array}{r}\text { Inter. } \\
1.64 \\
\end{array}$ & & $\begin{array}{c}\text { Salinity } \\
1.12 \\
\end{array}$ & $\begin{array}{l}\text { Bio. } \\
\text { 0.27 }\end{array}$ & $\begin{array}{c}\text { Inter. } \\
1.60 \\
\end{array}$ & & \\
\hline
\end{tabular}

L.S.D $_{(0.05)}=$ Least significant differences at 0.05 level of probability.

the role played by biofertilizers in controlling soil sodicity, via absorption of $\mathrm{Na}^{+}$ions from soil solution These results are in agreement with those of Hwang and Yoon (1995), and Ottai et al.,(2006).

\section{2- Soil Nutrients Availability}

Data on the influence of the tested treatments on the $\mathrm{N}, \mathrm{P}$ and $\mathrm{K}$ availability $\left(\mathrm{mg} \mathrm{kg}^{-1}\right)$ in the soil are presented in Table (8). Statistical analysis of these data revealed that applied the high biofertilizers rate to soil recorded the significantly highest $\mathrm{N}, \mathrm{P}$ and $\mathrm{K}$ availability at the end of the two seasons, giving values of $67.83,40.36$ and $96.52\left(\mathrm{mg} \mathrm{kg}^{-1}\right)$, respectively in the first season, and 70.78, 41.33 and $96.96\left(\mathrm{mg} \mathrm{kg}^{-1}\right)$, respectively, in the second season for the above mentioned parameters) comparing with that recorded from the control treatment. Concerning the effect of saline water irrigation, it is obvious from the tabulated data the significant decreased on $\mathrm{N}, \mathrm{P}$ and $\mathrm{K}$ availability due to irrigated the plants with the saline water at any concentration (EC,2,4,8d $\mathrm{dSm}^{-1}$ ) compared with control in both experimental trials.

For the interaction, increasing rates of biofertilizers at any given level of water salinity increased the amounts of available $\mathrm{N}, \mathrm{P}$ and $\mathrm{K}$. slight decreases in the amounts of $\mathrm{N}, \mathrm{P}$ and $\mathrm{K}$ availability with increasing $\mathrm{EC}$ of water salinity at any given biofertilizers rate. Increasing availability of N,P and $\mathrm{K}$ with biofertilizers application seems to be associated with the $\mathrm{pH}$ reduction $($ Table, 8$)$ and the formation of soluble metal organic 
Table 8. Effect of biofertilizers, water salinity and their interaction on $N, P$ and $K$ availability $\left(\mathrm{mg} \mathrm{kg}^{-1}\right)$ in the growing medium of Hibiscus sabdariffa, L. cv. "Sabhia 17" plants during the 2008 and 2009 seasons

\begin{tabular}{|c|c|c|c|c|c|c|c|c|c|c|}
\hline \multirow{3}{*}{$\begin{array}{c}\text { Compost } \\
\text { rate, } \\
\text { m }^{3} \text { fed }^{-1}\end{array}$} & \multicolumn{10}{|c|}{ Water salinity ( EC, $\mathrm{dS}^{-1}$ ) } \\
\hline & T.W & 4 & 8 & 12 & Mean & T.W & 4 & 8 & 12 & Mean \\
\hline & \multicolumn{10}{|c|}{ Av- N $\left(\mathrm{mg} \mathrm{kg}^{-1}\right)$} \\
\hline & \multicolumn{5}{|c|}{$\left(1^{\text {st }}\right)$ season } & \multicolumn{5}{|c|}{$\left(2^{\text {nd }}\right)$ season } \\
\hline $\mathbf{0}$ & 44.38 & 38.64 & 33.30 & 29.42 & 36.43 & 43.92 & 38.65 & 33.18 & 28.35 & 36.02 \\
\hline 2.5 & 56.56 & 55.99 & 53.21 & 50.72 & 41.44 & 56.70 & 56.23 & 54.87 & 52.01 & 54.95 \\
\hline 5 & 63.97 & 61.45 & 60.34 & 58.63 & 61.10 & 64.05 & 63.33 & 60.00 & 62.34 & 62.43 \\
\hline 10 & 74.36 & 78.39 & 65.84 & 61.74 & 67.83 & 75.93 & 78.46 & 66.21 & 62.53 & 70.78 \\
\hline Mean & 59.82 & 58.61 & 53.17 & 50.13 & & 60.15 & 59.16 & 53.65 & 51.31 & \\
\hline \multicolumn{2}{|c|}{ LSD $5 \%$} & $\begin{array}{l}\text { Salinity } \\
0.62\end{array}$ & $\begin{array}{l}\text { Bio. } \\
0.19\end{array}$ & $\begin{array}{l}\text { Inter. } \\
1.27\end{array}$ & & $\begin{array}{c}\text { Salinity } \\
0.62\end{array}$ & $\begin{array}{l}\text { Bio. } \\
0.22 \\
\end{array}$ & $\begin{array}{c}\text { Inter. } \\
1.18\end{array}$ & & \\
\hline & \multicolumn{10}{|c|}{ Av- $P\left(\mathrm{mg} \mathrm{kg}^{-1}\right)$} \\
\hline $\mathbf{0}$ & 8.95 & 8.03 & 6.36 & 5.19 & 7.13 & 7.89 & 7.22 & 6.54 & 6.04 & 6.92 \\
\hline 2.5 & 15.64 & 14.28 & 13.86 & 11.34 & 13.78 & 15.39 & 13.96 & 12.17 & 13.74 & 13.81 \\
\hline 5 & 32.85 & 32.10 & 30.17 & 17.92 & 28.26 & 33.64 & 34.28 & 31.38 & 18.32 & 29.40 \\
\hline 10 & 46.86 & 46.37 & 35.12 & 33.10 & 40.36 & 46.71 & 47.94 & 37.52 & 33.17 & 41.33 \\
\hline Mean & 26.07 & 25.19 & 21.38 & 16.89 & & 25.90 & 25.85 & 21.90 & 17.82 & \\
\hline \multicolumn{2}{|c|}{ LSD 5\% } & $\begin{array}{l}\text { Salinity } \\
0.49\end{array}$ & $\begin{array}{l}\text { Bio. } \\
2.74\end{array}$ & $\begin{array}{l}\text { Inter. } \\
4.32\end{array}$ & & $\begin{array}{c}\text { Salinity } \\
0.41\end{array}$ & $\begin{array}{l}\text { Bio. } \\
2.97\end{array}$ & $\begin{array}{l}\text { Inter. } \\
5.11\end{array}$ & & \\
\hline & \multicolumn{10}{|c|}{ Av- K ( mg kg $\left.{ }^{-1}\right)$} \\
\hline $\mathbf{0}$ & 79.68 & 73.75 & 65.90 & 63.49 & 70.70 & 76.38 & 73.82 & 66.75 & 63.27 & 70.05 \\
\hline 2.5 & 84.97 & 80.97 & 78.74 & 74.22 & 79.72 & 84.27 & 83.72 & 80.14 & 76.49 & 81.15 \\
\hline 5 & 91.49 & 91.95 & 87.92 & 85.87 & 90.80 & 94.18 & 94.93 & 90.38 & 86.74 & 91.56 \\
\hline 10 & 97.85 & 97.43 & 95.97 & 94.86 & 96.52 & 98.39 & 97.90 & 94.25 & 94.30 & 96.96 \\
\hline Mean & 88.49 & 86.02 & 82.13 & 79.61 & & 88.30 & 87.59 & 82.88 & 80.95 & \\
\hline \multicolumn{2}{|c|}{ LSD $5 \%$} & $\begin{array}{l}\text { Salinity } \\
1.19\end{array}$ & $\begin{array}{l}\text { Bio. } \\
2.23\end{array}$ & $\begin{array}{l}\text { Inter. } \\
3.98\end{array}$ & & $\begin{array}{c}\text { Salinity } \\
1.10\end{array}$ & $\begin{array}{l}\text { Bio. } \\
2.62\end{array}$ & $\begin{array}{l}\text { Inter. } \\
3.59\end{array}$ & & \\
\hline
\end{tabular}

L.S.D $_{(0.05)}=$ Least significant differences at 0.05 level of probability. matter complexes (Cole et al.,1994). These results agree with those of Awad (1994) and Wasif et al., (1995).

\section{REFERENCES}

Abdalla, A. M.;F. A. Rizk, and S. M. Adam. 2001. The pproductivity of pepper plants as influenced by som biofertilizer treatments under plastic house conditions. Bull. Agric. Cairo Univ., 52(4):625-639.

Abd El- Fattah, A.E. 1998. Effect of bio and mineral phosphate fertilization on growth and productivity of globe artichoke (Cynara scolymus, L.) under newly reclaimed calcareous siol conditions. Assiut J. Agric. Sci.,29 (3):234-246.

Abo El- Nour, E.A.A. ; A.A. El-Sayed and A.A. El-Bendary. 1996. Effect of phosphate biofertilizer (Phosphorein) on growth, yield and nutrient uptake of faba bean plants. J. Agric. Sci., Mansoura Univ. 21:477-483.
Abou El-Khashab, A.M. 2003. Growth and chemical constituents of some olive cultivars as affected by biofertilizers and different water regimes. Egypt, J. Agric. Res.2: 243-265.

Afifi, M.Y.; T.A.Ahmed, and N.M.Atyia. 1998. Effect of some management practices on salinity regime of soil under irrigation with diluted sea water. Egypt, J. Siol Sci.38,No. 1-4, pp:413-423.

Attia, E. M. 2000. Using different forms of agricultural managements to produce henna (Lawsonia inermis) with minimized pollution under North -Sinai conditions. Ph.D. Thesis, Ain Shams Univ.

Awad, A.M.A. 1994. Crop residues effects on soil organic matter, wheat yield and nutrients dynamics. Ph.D. Thesis, Fac.of Agric. Alex. Univ. Egypt. 
Barsoom, S.W. 1998. Comparative effects of inoculation with VA-mycorrhyzal fungi and organic matter addition on phosphorus and micronutrientsuptake by maize. Egypt. J. Soil Sci. 38:21-33.

Cole, M.A., X. Liu and L. Zhang. 1994. Plant and Microbial Establishment with Compost In Bioremediation Through Rhizosphere Technology,edided by T.A.Anderson and J.R. Coats. pp: 210-222. Washington, DC:American Chemical Society.

Dhillon, S.S. 1987. Influence of varied phosphorus supply on growth and xylem cytokinin level of Sycamore (Platanus occidentalis, L.) seedlings. Plant Physiol. 61:521-524.

EL-Kouny, H.M. 1999. Evaluation of Compost Production and its Properties with Special References Compost Extract. Ph.D. Thesis Fac. Agric. Alex. Univ., Egypt.

EL-Kouny, H.M. 2002. Effect of organic fertilizers (compost) at different rates of application under salinity stress condition on soil and Tomato plant. Minufiya J. Agric. Res. 27:355.

El- Kouny, H.M., A.I. Sharafe and A.H. El-Naggar. 2004. Effect of compost application and saline irrigation water on the production of Roselle plants cultivated in lacustrine soil. J. Adv. Agric. Res. Fac. Agric. Saba Basha 4:909.

El- Kouny, H.M.,R.I.Fayed and A.M.Daoud. 2010. Influence of organic manure compost on soil properties and performance of roselle (Hibiscus sabdariffa,L.) irrigated with different levels of saline water. Minufiya J. Agric. Res.35(3):1111-1124.

El-Gamal, A.M. 1996. Response of potato in newly reclaimed areas to mineral nitrogen fertilizer levels and nitrogen fixing biofertilizer Halex 2. Assiut J. Agric. Sci. 27: 8999.

El-Naggar, A. H. M. 2010. Effect of biofertilizer, organic compost and mineral fertilizers on the growth, flowering and bulbs production of Narcissus tazetta, L. J. Agric. \& Env. Sci. Alex., Egypt. 9 (1): 24-52.

El-Naggar A. A. M. and R. M. R. Hedia. 2005. Effect of Interaction between Biofertilizers and Organic or Mineral Fertilizers on Soil OC, NPK Availability and Production of Narcissus Tazetta, L. Alex. J. Agric. Res. 50 (1): 143 157.

El-Sayed . S.G. 2003. physiclogica studied on some oramental shrubs Ph . D . thesis, Faac of Agric El-Kafr El-Sherkn Tanta Univ, Egypt .

El-Sayed,S.G. and A.H.M.El-Naggar. 2008. Response of poinsettia plants grown in sandy desert soils to saline irrigation and organic manures. J. Agric. \& Env. Sci. Alex., Egypt. 7 (2): 24-52.

Fahmy, R. (1970). Different quantitave estimation of some organic compounds in plant. Soc. Hort.155 : 72-79.

Gaur, A. C. and K. P. Ostwal. 1972. Influence of phosphate dissolving Bacilli on yield and phosphate uptake of wheat crop. Indian J. Exp. Biol. 10:393-394.

Holcomb, J. (1984). growing in sewage sludge compost. Hort .Abst. $45: 4638$.
Hwang, S. and H. Yoom. 1995. The effect of salt concentration on the growth of chrysathenum, carnation and gerbera in green house soil. Hort. Abst. 58:10871.

Jayathilake, P.K.S.; I.P. Reddy ; D. Srihari and G. Neeraja. 2002. Effect of nutrient management on growth, yield and yield attributes of rabi onion (Allium cepaL.). Vegetable Science. 2: 184-185.

Khalid, M.E.A., N.M. Badran and M.A.A. El-Emam. 2000. Effect of different organic manures on growth and nutritional status of corn. Egypt. J. Soil Sci. 40:245-263.

Koreish, E.A. 2003. Comparative study of different biofertilizers mixtures on faba bean and wheat yield in newly-reclaimed soils. J. Agric. Mansoura Univ. 28:41914205 .

Koreish, E. A. ; M. E. El-Fayoumy, H. M. Ramadan and W. H. Mohamed. 2004. Interaction effect of organic and mineral fertilization on faba bean and wheat productivity in calcareous soils. Alex,. J. Agric. Res.2:101-114.

Krasilnikov, M.1972. On the role of soil bacteria in plant nutrition. J. Gen. Appl. Microbiol. 7:128-144.

Marschner, K. 1986. Mineral Nutrition in Higher Plants. Academic Press, Harcourt Brace Jovanovish, Publishers, pp.674.

Moor, K.A. 2000. Comparison of Salvia growth in Seaweed compost and biosolids compost. Compost Sci. and Utilization 8:24.

Morsy, A.M.(2003). Effect of irrigation water quality on the soil physical and hydrological properties in Western Delta region .Alex. Sci. Exch. 24 : 458.

Moran, R. and Porath, D. 1980. Chlorophyll determination in intact tissues using $\mathrm{NN}$ - dimethyl formamid. Plant Physiol., 65: 478-479.

Mostafa, M. M. 2002. Effect of biofertilizer, salinity and magnetic technique on the growth of some annual plants. Alex. J. Agric. Res. 47 (2): 151 -162.

Nofal , E; M.A. El-Tarawy and E.M. Badawy (1983) Effect of sodium and calcium chorides in soil on the growth and chemical analysis of adhatoda and Thuga orientalis J.Agric Res. Tanta Univ . 9(1):150-162 .

Ottai, I.M.E.S., L.K.A. Aboud, L.T.M. Mahmoud and D.M. EL-Hariri. 2006. Stability Analysis of Roselle cultivars (Hibiscus sabdraffia,L.) under different nitrogen fertilization. Enviro. world J. Agric. Sci. 2 : 333.

Osbrien, T. and A. Barker 1996. Growth of peppermint in compost .J. Herbs Spices and Medical plants 4:19.

Page, A.L, R.H. Miller and D.R. Keeney. 1982. Methods of Soil Analysis. Am. Soc. Agron. Madison, Wisconsin, USA.

Pokorna Kozova, J. 1984. Effect of long term fertilization on the dynamics of change of soil organic matter. Zentralblatt-fur mikrobiologie. 7: 497-504.

Ramadan, H.M.; E.A. Koreish; H.M. Gaber and M.E. ElFayoumy. 2002. Assessment and comparison of bio and mineral fertilization on farm profitability in different newly-reclaimed soils. Alex. J. Agric. Res. 47:133-146. 
Rather, S. A.; N. Ahmed and M.A. Chattoo.2003. Response of onion to microbial inoculation and chemical nitrogen. Haryana J, Hort. Sci.3/4: 270-271 .

Reddy, P. S. Rao, T. V. S. S. Venkataramana, P. Suryanarayana, N.2003. Response of mulberry varieties to VAM and Azotobacter. 2:171-174.

Shaban, K.H.A. and A.M. Helmy 2006. Response of wheat to mineral and Bio-fertilization under saline conditions .Zagazig J. Agric.Res.33 : 1189.

Shalan, M.N., T. A. Abd-Ellatif, S.G.I. Soliman and E.O. ElGaawwas. 2001. Effect fo some chemical and biofertilizer treatments on roselle (Hibiscus sabdariffa, L.) plants. Egypt. J. Agric. Res. 79:587-606.

Snedecor, G. and W.Cochran , 1981. Statistical Methods. Seventh Ed., Iowa State Univ. Iowa, USA.
Tarafdar, J. C. and N. Claassen. 1988. Organic phosphorus compounds as a phosphorus source for higher plants through the activity of phosphatases produced by plant roots and microorganisms. Biol Fertil Soil. 5:308-312.

Wange, S. and L. Patil. 1994. Response of Tuberose to biofertilizers and nitrogen. J. Maharshata Agric. Uni.19: 484-485.

Wareing, P.F., and I.D. Phillip.1974. The control of growth and differentiation in plants, pergamon Press Ltd Oxford.

Wasif, M.M., M.M.K.Shabuna, S.M.Sead, S.E. El-Maghrby and H.A. Ashour. 1995. Influence of some calcareous soil properties and its productivity of wheat under highly saline irrigation water. Egypt J. Soil Sci..35.

Westerman, R.L. 1990. Soil Testing and Plant Analysis. ( $3^{\text {rd }}$ ed) Soil Science Society of America, Inc. Madison Wisconsin, USA.

Xia, M.Z. and F.Q.Xiong. 1991. Interaction of molybdenum, phosphorus and potassium on yield of Vicia faba. J. Agric. Sci.1: 85-89. 


\section{الملخص العربي}

تأثير التسميد الحيوي على النمو الخضري والخصول لنبات الكركديه تحت تركيزات مختلفة

\section{لملوحة مياه الري}

$$
\text { على حسن النجار، حامد مبروك القونى }
$$

للأوراق) والمعصول (عدد الثمار والوزن الطازج والجـاف للثمار)

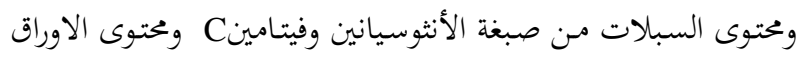
من الكلوروفيل الكلى والعناصر المعدنية وقد تحققت أعلى زيادة عند

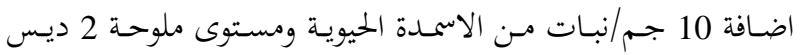

سيمنز.

كمـا لـوحظ انخفـاض معنـوي في رقم الحموضـة (pH) و ملوحسة

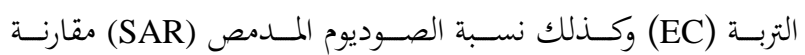
بالكنترول وذلك عند اضافة الاسمدة الحيوية و جميع مستويات ملوحة ودات

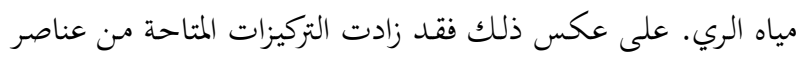

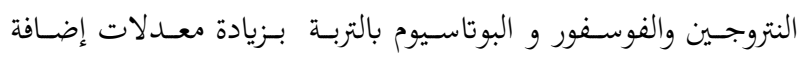

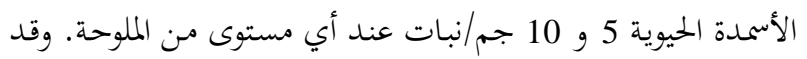
تحققت أعلى زيادة في تركيزات هذه العناصر عند اضافة 10 جم/نبات

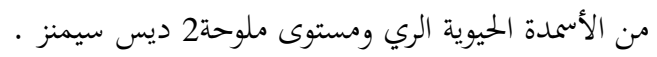

[Hibiscus [ أجريست التجربـة علسى نبـاتات الكركديـهـ sabdariffa,L. c v. "Sabahia 17"] متتاليين 2009/2008 تحت ظروف الحقل بمحطة بحوث الأراضي

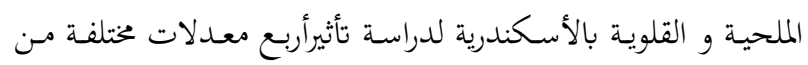
الأسمدة الحيوية النتروبين والفوسفورين Nitrobine+Phosphorein] (NP)1:1w/w]

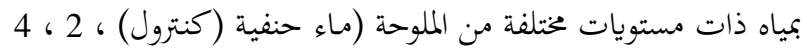

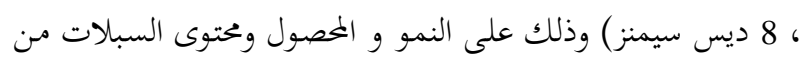

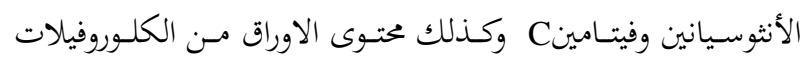

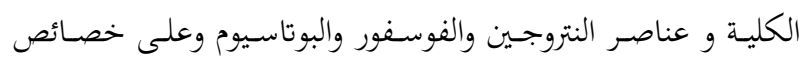

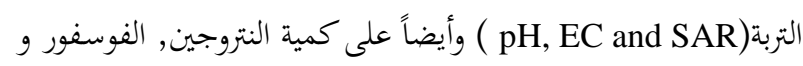

$$
\text { البوتاسيوم المتاح فن التربة. }
$$

أوضـحت النتائج أن زيادة معـلاتات إضـافة الأسمـدة الحيويـة أدت إلي

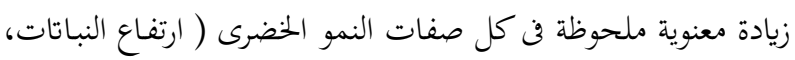

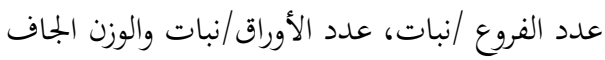

